\title{
How Important Is Financial Risk?
}

\author{
Söhnke M. Bartram, Gregory W. Brown, and William Waller*
}

\begin{abstract}
We explore the determinants of equity price risk of nonfinancial corporations. Operating and asset characteristics are by far the most important determinants of risk. For the median firm, financial risk accounts for only $15 \%$ of observed stock price volatility. Furthermore, financial risk has declined over the last 3 decades, indicating that any upward trend in equity volatility was driven entirely by economic risk factors. This explains why financial distress (as opposed to economic distress) was surprisingly uncommon in the nonfinancial sector during the 2007-2009 crisis even as measures of equity volatility reached unprecedented highs.
\end{abstract}

\section{Introduction}

The 2007-2009 financial crisis has brought significant attention to the effects of financial leverage. Despite the seizing of capital markets during the crisis, problems in the U.S. nonfinancial sector have been relatively minor compared to the distress in the financial sector. For example, nonfinancial bankruptcies have been limited despite the fact that the economic decline is the largest since the Great Depression of the 1930s. In fact, bankruptcy filings of nonfinancial firms have occurred mostly in U.S. industries that faced fundamental economic pressures before the financial crisis (e.g., automotive manufacturing, newspapers, and real estate). This surprising fact raises the question, "How important is financial risk for nonfinancial firms?"

Although the study of leverage and financial risk is ubiquitous in financial economics, there is little work on fundamental determinants of risk at the firm level. Some older studies dating back as far as Rosenberg and McKibben (1973)

*Bartram, s.m.bartram@wbs.ac.uk, Warwick University, Business School, Coventry CV4 7AL, UK; and Brown (corresponding author), gregwbrown@unc.edu, Waller, william_waller@unc.edu, University of North Carolina-Chapel Hill, Kenan-Flagler Business School, Chapel Hill, NC 27599. Helpful comments and suggestions provided by Michael Halling, Allaudeen Hameed, Michael Lemmon, Richard Phillips, Gunter Strobl, Avi Wohl, and seminar participants at the 2009 American Finance Association annual meeting, the 2013 European Finance Association annual meeting, the 2009 Financial Intermediation Research Society Conference in Prague, the Bank of England, the Cass Business School, the University of North Carolina-Chapel Hill, Tel Aviv University, and Texas Christian University are gratefully acknowledged. The paper has also benefited from comments by Paul Malatesta (the editor) and Tim Simin (the referee). We thank Jaewon Choi and Matthew Richardson for sharing with us their sample of firms. Murat Atamer provided excellent research assistance. 
find that firm operating and financial characteristics such as size, profitability, and leverage are important for explaining equity risk factors. Christie (1982) documents a strong relation between changes in stock price volatility and financial leverage. However, Schwert (1989) finds that leverage explains a relatively small part of the movements in stock volatility. Despite these differences in findings, the precise determinants of equity market volatility remain relatively unexplored.

Using a more recent and comprehensive sample of U.S. firms, we reexamine the issue of financial risk in light of the financial crisis of 2008. The primary result of our analysis is surprising: Measures of implied financial risk are small for most firms. Instead, factors determining economic risk for a typical company appear to explain the vast majority of the variation in equity volatility. Only for a small fraction of the most highly levered firms in our sample are financial risks greater than economic risks. We find that our implied measures of financial risk that take into account all effects of financial policy on risk are much lower than would be suggested by just measuring total debt relative to firm value. For example, actual financial (market) leverage ${ }^{1}$ is about 1.50 compared to our implied estimates of between 1.03 and 1.11 (depending on model specification and estimation technique) in our sample covering 1964 to 2009. Moreover, using the volatility decomposition method described in Choi and Richardson (2009), we find that asset volatility accounts for $84.7 \%(67.6 \%)$ of total volatility for the median (average) firm in our full sample. This result suggests that firms manage financial risk by undertaking financial policies that lower exposure to relatively low levels. These policies likely include choosing (and adjusting) financial variables such as debt levels, debt maturity, dividend policies, or cash holdings in response to realized or anticipated business risks (see, e.g., Acharya, Almeida, and Campello (2007), Bates, Kahle, and Stulz (2009)). In addition, firms may use explicit financial risk management techniques such as the use of financial derivatives, contractual arrangements with investors (e.g., lines of credit, call provisions in debt contracts, or contingencies in supplier contracts), special purpose vehicles, or other alternative risk transfer techniques that are typically hard to observe (see, e.g., Bartram, Brown, and Fehle (2009)). For example, we estimate the impact of interest rate derivative usage on a subsample of our firms and find that derivative usage is associated with significantly lower financial risk.

Compared to extant research, we take a different tack by focusing on the decomposition of risk into two components: economic and financial. We seek to understand the determinants of equity price risk at the firm level by considering total risk as the combination of risks inherent in the firms' operations (i.e., economic or business risks) and risks associated with financing the firms' operations (i.e., financial risks). We then attempt to assess the relative importance of economic and financial risks and the implications of these risks on financial policy.

Our goal of identifying the important determinants of equity price risk (volatility) relies on viewing financial policy as transforming asset volatility into equity volatility via financial leverage. Thus, we consider financial leverage the wedge between asset volatility and equity volatility. For example, in a static setting,

\footnotetext{
${ }^{1}$ Market leverage is defined as the market value of equity plus total debt (net of cash) as a percentage of the market value of equity. Thus, a value of 1.0 represents no financial leverage.
} 
financial leverage magnifies operating profits available to equity holders. Because financial policy is determined by owners (and managers), we are careful to examine the effects of firms' asset and operating characteristics on financial policy.

For our study, we use a large sample of nonfinancial firms in the United States from 1964 to 2009 . We conduct two primary types of empirical analysis to assess sources of equity volatility. First, we allow economic risk to be a determinant of financial policy in the structural framework of Leland and Toft (LT) (1996). An advantage of this structural model approach is that we are able to account for the possibility of both financial and operating implications of some factors (e.g., dividends), as well as the endogenous nature of the bankruptcy decision and financial policy in general. A disadvantage of this approach is that our results could depend on the form of the structural model (see Eom, Helwege, and Huang (2004)). Second, we take a time-series approach to examine determinants of equity volatility by estimating an augmented exponential generalized autoregressive conditional heteroskedasticity (EGARCH) model (Nelson (1991)) that allows the long-run component of risk to be determined by firm-specific business and financial risk factors. ${ }^{2}$ The primary advantage of this model is that it incorporates known features of equity price dynamics, such as volatility clustering. A potential disadvantage of this approach is that there is no structural interaction between business and financial risks. ${ }^{3}$

The effects of our economic risk factors on equity volatility are often highly statistically significant, with predicted signs, and the magnitudes of the effects are substantial. We find that the volatility of equity returns decreases with the size and age of the firm. This finding is intuitive as large and mature firms typically have more stable lines of business, which should be reflected in the volatility of equity returns. Larger and older firms are also more likely to have risk management programs, which tend to lower financial risks (see Bartram, Brown, and Conrad (2011)). Equity volatility tends to decrease with capital expenditures. Consistent with the predictions of Pástor and Veronesi (2003), we find that firms with higher profitability and lower profit volatility have lower equity volatility. Among the variables we consider, the effects on equity volatility of firm size, profit volatility, and dividend policy stand out as most important.

Of particular interest is our finding that measures of implied financial leverage declined significantly between the late 1970s and the late 1990s. Over this same period measures of equity price risk (such as idiosyncratic risk) increased. In fact, measures of implied financial leverage from our structural model settle near 1.0 (i.e., no leverage) by year 2000. Our evidence suggests several reasons for this trend. First, total debt ratios for nonfinancial firms have declined steadily over the last 30 years, so our measure of implied leverage should also decline. Second, firms have significantly increased cash holdings, so measures of net debt

\footnotetext{
${ }^{2}$ This model is similar to the approach employed by Choi and Richardson (2009) and allows for nearly direct comparisons with their results.

${ }^{3}$ To a large degree, these modeling trade-offs are irrelevant for our conclusions since the primary results of our analysis are also evident in univariate sorts on firm volatility as well as from estimates of simple panel regressions. However, more careful analysis is required to determine if the results are driven by endogeneity, volatility clustering, and so on.
} 
(debt minus cash and short-term investments) have also declined. Third, the composition of publicly traded firms has changed, with more risky firms (especially technology-oriented firms) becoming publicly listed. These firms tend to have less debt in their capital structure. Fourth, firms appear to be undertaking a variety of financial activities (e.g., risk management with derivatives) that have reduced financial exposures. For example, we document that the aggregate interest expense net of changes in cash holdings has declined to zero over the last 30 years in a way that closely mimics the decline in our implied leverage measures. ${ }^{4}$

We conduct a battery of additional tests to examine the robustness of our results. We repeat our analysis with a reduced-form model that imposes minimum structural rigidity on our estimation and obtain results that are very similar to those from the structural model and time-series model. We undertake a simulation study of the structural model to identify any inherent biases resulting from our specification and find that any biases related to misspecification of the asset volatility function are likely small. However, we find some evidence that misspecification of debt levels in the LT (1996) model could have a downward bias on our estimates of leverage. We make bias adjustments to assess the effects of this problem and show that we still observe low and declining financial risk over the last 3 decades. We also estimate the models on various subsamples of firms (e.g., partitioned by debt levels) and find that estimated parameters and implied risk measures follow expected (and intuitive) patterns.

The paper is organized at follows: Motivation, related literature, and hypotheses are reviewed in Section II. Section III describes the models we employ, followed by a description of the data in Section IV. Empirical results for the LT (1996) model and the time-series model are presented in Section V. Section VI considers robustness tests. Section VII concludes. An Internet Appendix (available at www.jfqa.org) includes details of many robustness tests and alternative specifications.

\section{Motivation and Hypotheses}

Economic risk can be thought of as uncertainty regarding the value of the firm's assets and the future profits of the company. These are the "real" risks a company faces and include uncertainty about the market for a firm's products, the cost and availability of factor inputs to production, and the risks of competition and innovation, among others. Prior research has modeled this type of uncertainty in various ways. For example, in the Merton (1974) setting, economic risk is modeled as uncertainty in the underlying asset value of the firm. Other research models economic risk as uncertainty about the level of firm profitability. Empirically it may be important to consider risks related to both a firm's assets and its profitability. For example, consider two firms with identical profit characteristics, but the assets of one firm are composed of a greater proportion of intangible assets. The firm with fewer tangibles may be riskier if the recovery value upon

\footnotetext{
${ }^{4}$ The decline in this measure is driven by a combination of lower debt, lower interest rates and increased cash holdings. We cannot say if this is an optimal response to changes in other firm characteristics (such as higher asset volatility), but it is a dramatic and systematic shift.
} 
bankruptcy is lower. For this reason, we characterize the qualities of both assets and profitability in our analysis.

We hypothesize that larger firms are likely to have a more diversified customer base and a longer operating history. Both of these features suggest that larger firms should be less risky. As noted already, tangible assets (property, plant, and equipment) serve as a proxy for the "hardness" of a firm's assets and may lose less of their value upon bankruptcy (Gilson (1997)). The ratio of capital expenditures to total assets serves as a measure of a capital intensity as well as growth potential. ${ }^{5}$ Higher capital intensity is typically associated with higher operating leverage (i.e., a higher proportion of fixed costs), whereas higher growth opportunities imply that firm value depends more on distant cash flows. Both of these characteristics magnify variations in operating profits.

We characterize firm profitability in two ways. First, we consider the level of profitability (operating margin before depreciation) as a measure of economic risk. A firm with a high operating margin is likely to be less risky for several reasons. High profit margins may be a sign of low product market competition. In addition, financial distress is often triggered by an adverse economic shock. As such, a more profitable firm is likely to be far from financial distress and, therefore, less likely to have equity returns magnified by variations in expected bankruptcy costs. Higher profit levels may also suggest that more of a firm's value comes from relatively near-term cash flows, which are likely to be less uncertain. Second, we consider the volatility of profits. As discussed above, Pástor and Veronesi (2003) show the direct relation between profit risk and equity price risk in a setting where investors must learn about the long-run profitability of a company.

We also use a variety of firm-specific characteristics to describe the financial risks a firm's shareholders face. The most fundamental financial risk stems from debt financing. In a perfect markets setting, debt has a direct effect on volatility of equity returns and, therefore, on our measure of total firm risk. However, theoretical research suggests that firms choose the optimal amount of debt as a function of economic risk, so the actual relation is again an empirical issue. We also consider cash holdings because they act as liquid reserves and hypothesize that firm risk should have a negative relation with cash holdings if cash acts as "negative debt." On the other hand, Opler, Pinkowitz, Stulz, and Williamson (1999) and Acharya et al. (2007) find that cash is not just negative debt but instead serves the role of precautionary savings to ensure against underinvestment. The maturity of debt used by firms may also determine the level of firm risk. For example, firms using relatively more short-term debt may be more exposed to interest rate fluctuations and roll-over risk and, therefore, have higher levels of total risk.

Dividend policy can also affect the level of firm risk for several reasons. First, Pástor and Veronesi (2003) show that firms not paying dividends have higher return volatility than do dividend payers. For dividend payers, equity value depends less on terminal firm value and more on (relatively) near-term dividends, which are less sensitive to operating performance (i.e., average profits). Dividends may also serve as a signaling device for managers who wish to communicate

\footnotetext{
${ }^{5}$ We also consider the market-to-book ratio as a measure of growth potential.
} 
strong prospects, and thus lower risk, for their companies. Intuitively, dividends are more commonly paid by mature firms with more stable lines of business and fewer growth opportunities. In this case, dividends act more as an indicator of economic risk than financial risk. On the other hand, large more mature firms that pay dividends are also more likely to have sophisticated treasury operations that would carefully manage financial risk (e.g., with derivatives) (Bartram, Brown, and Fehle (2009)).

\section{Models of Firm Risk}

The relation between financial risk and economic risk is likely to be affected by the endogenous nature of financial decision making (e.g., firms with low economic risk can afford higher debt levels). To account for the importance of firmspecific characteristics on financial decision making, we use two general empirical approaches in our analysis as well as variants of these methods. Our first approach employs the structural model of LT (1996). Our second approach explicitly considers the well-documented time-series properties of equity volatility by incorporating firm-specific characteristics into an augmented EGARCH model.

\section{A. Leland-Toft Model}

The Leland and Toft (LT) (1996) model provides a specific structural form for describing total firm risk. More specifically, the LT model builds on the observation made by Black and Scholes (1973) and Merton (1974) that the equity of a firm resembles a call option on the firm's assets. The LT model generalizes the Merton model in several ways. Bankruptcy can occur anytime (similar to Black and Cox (1976)). In addition, bankruptcy is assumed to be an endogenous event triggered by equity holders to maximize equity value. The model allows a finite average maturity $(T)$ for debt, tax-deductible coupon payments $(C)$, default costs $(\alpha)$, and net cash payouts $(\delta)$ to security holders. As such, the LT framework combines the Merton model with both trade-off theory (i.e., tax benefits vs. bankruptcy costs related to leverage) and agency theory (e.g., asset substitution).

To estimate the model, we minimize the squared deviations of predicted equity volatility $\left(\sigma_{E}\right)$ from actual volatility. Following the LT (1996) model, we define

$$
\sigma_{E}=l\left(\sigma_{A}\right) \times \sigma_{A},
$$

which describes how asset volatility $\left(\sigma_{A}\right)$ is transformed into equity volatility by a function characterizing financial leverage, $l(\cdot)$, that is also a function of $\sigma_{A}$. We parameterize $\sigma_{A}$ in a straightforward, but admittedly ad hoc, fashion as an exponential function of economic risk variables to ensure positive values of $\sigma_{A}$. In the LT model

$$
l\left(\sigma_{A}\right)=\left[1+\frac{D(V ; \mathrm{VB} ; T)}{E(V ; \mathrm{VB} ; T)}\right] k\left(\sigma_{A}\right),
$$

where $D, E$, and $V$ are, respectively, the market value of debt, equity, and the firm's assets, and VB is the endogenous bankruptcy trigger. Note that $k\left(\sigma_{A}\right)$ is 
analogous to $N\left(d_{1}\right)$ in the Merton (1974) model. Section A of the Internet Appendix provides an in-depth discussion of the LT model as well as closed-form expressions for the model's parameters.

\section{B. Augmented EGARCH Model}

Although the LT (1996) model can be estimated with time-series, crosssectional, or panel data, the LT model does not incorporate well-documented time-series features of equity return volatility such as autoregressive conditional heteroskedasticity (volatility clustering). In addition, LT model misspecification could lead to biased estimates of implied leverage and its determinants (discussed in more detail later). Consequently, we take an alternative and completely independent approach to assessing the role of various firm characteristics. Specifically, we estimate an "augmented" EGARCH model (see Nelson (1991)) where volatility depends on return history and a set of firm characteristics $\left(X_{i, t}\right)$. The general model takes the form

$$
\begin{aligned}
r_{i, t} & =\sigma_{i, t} \varepsilon_{i, t}, \\
\ln \left(\sigma_{i, t}^{2}\right) & =X_{i, t} \delta+\beta \ln \left(\sigma_{i, t-1}^{2}\right)+\alpha\left(\left|\varepsilon_{i, t-1}\right|-\mathrm{E}\left|\varepsilon_{i, t-1}\right|\right)-\gamma \varepsilon_{i, t-1},
\end{aligned}
$$

where $r_{i, t}$ is the return for stock $i$ in period $t ; \alpha, \beta$, and $\gamma$ are typical EGARCH scalar parameters to be estimated; and the vector $\delta$ represents estimated coefficients for the firm characteristics (including a constant term). We estimate the model using stacked quarterly data. A major advantage of this model is that it allows firm-level characteristics to determine dynamic volatility across both firms and time.

\section{Data}

Our sample construction begins with firms that have accounting data in the Compustat database for any year between 1964 and 2009 and that have at least 125 nonzero daily stock returns in the Center for Research in Security Prices (CRSP) database during the year of the accounting data. We exclude utilities and financial services companies (industries 20 and 29 in the French classification of 30 industries, available at http://mba.tuck.dartmouth.edu/pages/faculty/ken.french/Data LLibrary/det_30_ind_port_old.html) because these firms are regulated and may therefore have different risk-taking incentives. In addition, we apply a variety of screens to our sample to focus on liquidly traded firms in periods of normal operations. The Internet Appendix provides a detailed discussion of these screens and a table of their effect on the sample size. It also provides a detailed discussion of variable construction. Overall, our sample covers the vast majority of the market value of U.S. firms excluding financials and utilities, an average of $90.7 \%$ of total market capitalization. Our proxy for firm risk is the volatility of common stock returns (the annualized standard deviation of daily returns). ${ }^{6}$

Table 1 provides summary statistics for our economic and financial risk variables, along with market equity volatility. In general, we observe significant

\footnotetext{
${ }^{6}$ We also conducted our primary analysis using weekly and monthly returns and found very similar results.
} 
TABLE 1

Summary Statistics and Correlations of Variables

Table 1 reports summary statistics and Pearson correlation coefficients among equity volatility, economic risk, and financial risk factors in columns, and various variables of interest in rows for the sample of annual data between 1964 and 2009. EQUITY_VOLATILITY is the annualized standard deviation of daily stock returns from the Center for Research in Security Prices (CRSP). In(SIZE) is the natural log of total assets (Compustat variable AT). Iog(AGE) is the difference between the measurement year and the minimum of i) year of listing data from Jovanovic and Rousseau (2001) and ii) the firm's initial appearance on the CRSP monthly database. TANGIBLE_ASSETS is gross property, plant, and equipment divided by total assets. CAPEX is capital expenditures divided by total assets. PROFITABILITY is operating income before depreciation divided by sales. PROFIT_VOLATILITY is the 5-year central standard deviation of profitability. DIVIDEND_YIELD is common dividends divided by market capitalization (absolute value of closing price $\times$ shares outstanding from CRSP). TOTAL_DEBT/MARKET_CAP is long-term debt plus current liabilities plus preferred stock divided by market capitalization. CASH/MARKET_CAP is cash and short-term price $x$ shares outstanding from CRSP). TOTAL_DEBT/MARKET_CAP is long-term debt plus current liabilities plus preferred stock divided by market capitalization. CASH/MARKET_CAP is cash and short-term and equity book value. DEBT_MATURITY is long-term debt divided by total debt. COUPON_RATE is interest expense plus preferred dividends divided by total debt. All accounting data items are from Compustat.

\begin{tabular}{|c|c|c|c|c|c|c|c|c|c|c|c|c|c|c|c|}
\hline & $\begin{array}{l}\stackrel{\complement}{\mathbb{N}} \\
\sum^{\mathbb{N}}\end{array}$ & $\begin{array}{l}\text { dे } \\
\text { Dे } \\
\text { के }\end{array}$ & 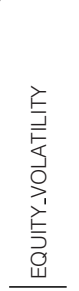 & 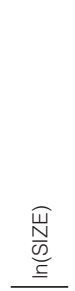 & 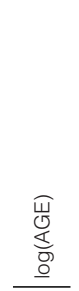 & 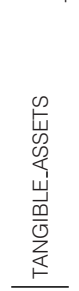 & $\frac{\text { 㟧 }}{\frac{\alpha}{0}}$ & 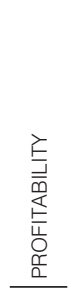 & 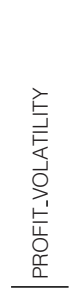 & 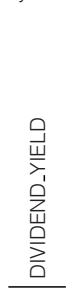 & 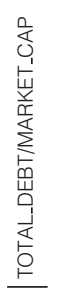 & 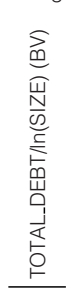 & 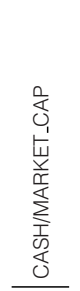 & 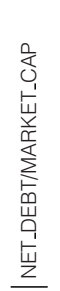 & 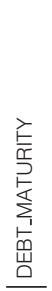 \\
\hline $\begin{array}{l}\text { EQUITY_VOLATILITY (annualized) } \\
\text { In(SIZE) }\end{array}$ & $\begin{array}{l}0.492 \\
290.3\end{array}$ & $\begin{array}{l}0.245 \\
1,664.0\end{array}$ & -0.36 & & & & & & & & & & & & \\
\hline $\log (A G E)$ & 11.9 & 2.5 & -0.39 & 0.49 & & & & & & & & & & & \\
\hline TANGIBLE_ASSETS & 0.537 & 0.365 & -0.24 & 0.22 & 0.24 & & & & & & & & & & \\
\hline CAPEX & 0.073 & 0.069 & -0.05 & -0.01 & -0.09 & 0.50 & & & & & & & & & \\
\hline PROFITABILITY & 0.100 & 0.187 & -0.41 & 0.32 & 0.16 & 0.28 & 0.20 & & & & & & & & \\
\hline PROFIT_VOLATILITY & 0.072 & 0.122 & 0.49 & -0.33 & -0.28 & -0.16 & 0.00 & -0.65 & & & & & & & \\
\hline DIVIDEND_YIELD & 0.013 & 0.019 & -0.44 & 0.20 & 0.37 & 0.25 & -0.02 & 0.16 & -0.27 & & & & & & \\
\hline TOTAL_DEBT/MARKET_CAP & 0.717 & 1.009 & 0.03 & 0.17 & 0.09 & 0.12 & -0.02 & 0.02 & -0.15 & 0.16 & & & & & \\
\hline TOTAL_DEBT/In(SIZE) (BV) & 0.435 & 0.201 & -0.08 & 0.31 & 0.14 & 0.16 & 0.06 & 0.07 & -0.21 & 0.08 & 0.59 & & & & \\
\hline CASH/MARKET_CAP & 0.138 & 0.156 & 0.22 & -0.10 & -0.08 & -0.18 & -0.16 & -0.25 & 0.20 & -0.04 & 0.21 & -0.08 & & & \\
\hline NET_DEBT/MARKET_CAP & 0.579 & 0.989 & -0.01 & 0.19 & 0.10 & 0.15 & 0.01 & 0.06 & -0.19 & 0.17 & 0.99 & 0.61 & 0.05 & & \\
\hline DEBT_MATURITY & 0.358 & 0.275 & -0.15 & 0.28 & 0.11 & 0.35 & 0.19 & 0.18 & -0.11 & 0.10 & 0.38 & 0.58 & -0.11 & 0.41 & \\
\hline COUPON_RATE & 0.036 & 0.027 & -0.05 & 0.13 & 0.09 & 0.28 & 0.11 & 0.08 & -0.06 & 0.09 & 0.39 & 0.48 & -0.12 & 0.41 & 0.62 \\
\hline
\end{tabular}


variation for all variables of interest. Table 1 also reports the correlations between the variables of interest. The correlation coefficients between equity volatility and economic risk variables are typically large in absolute value (capital expenditures is the exception). For financial risk variables, however, the results are not nearly as strong as for economic risk variables and sometimes counterintuitive. For example, cash holdings are positively related to equity volatility (consistent with the precautionary savings motive). Surprisingly, equity volatility is essentially uncorrelated with the leverage measures, and dividends are strongly and negatively related to equity volatility. This finding is consistent with the hypothesis that dividends are paid by more mature firms with more stable cash flows and inconsistent with dividends increasing financial leverage (i.e., net debt) and thus total risk. Another interesting finding is that financial risk variables are often highly correlated. For example, the pairwise correlations between net debt, debt maturity, and coupon rate are all greater than 0.40 .

\section{Results}

\section{A. Quartiles}

Table 2 provides summary statistics for variables by equity volatility quartiles, allowing us to obtain a feel for the economic significance of the correlations presented in Table 1. The results are dramatic and foreshadow the results of the multivariate estimations presented in the remainder of this article. When we

\section{TABLE 2}

\section{Means of Variables by Volatility Quartiles}

Table 2 reports the means of equity volatility, economic risk, and financial risk factors by volatility quartiles for the sample of annual observations between 1964 and 2009. EQUITY_VOLATILITY is annualized standard deviation of daily stock returns from the Center for Research in Security Prices (CRSP). In(SIZE) is the natural log of total assets (Compustat variable AT). $\log (A G E)$ is the difference between the measurement year and the minimum of i) year of listing data from Jovanovic and Rousseau (2001) and ii) the firm's initial appearance on the CRSP monthly database. TANGIBLE_ASSETS is gross property, plant, and equipment divided by total assets. CAPEX is capital expenditures divided by total assets. PROFITABILITY is operating income before depreciation divided by sales. PROFIT_VOLATILITY is the 5-year central standard deviation of profitability. DIVIDEND_YIELD is common dividends divided by market capitalization (absolute value of closing price $\times$ shares outstanding from CRSP). TOTAL_DEBT/MARKET_CAP is long-term debt plus current liabilities plus preferred stock divided by market capitalization. CASH/MARKET_CAP is cash and short-term investments (STI) divided by market capitalization. NET_DEBT/MARKET_CAP is (total debt - cash and STI) divided by market capitalization. TOTAL_DEBT/In(SIZE) (BV) is total debt divided by the sum of total debt and equity book value. DEBT_MATURITY is longterm debt divided by total debt. COUPON_RATE is interest expense plus preferred dividends divided by total debt. All accounting data items are from Compustat.

\begin{tabular}{|c|c|c|c|c|}
\hline & & Equity & uartile & \\
\hline & $1 \mathrm{st}$ & 2nd & $3 r d$ & 4th \\
\hline EQUITY_VOLATILITY (annualized) & 0.247 & 0.374 & 0.517 & 0.831 \\
\hline In(SIZE) (million) & 773.6 & 373.5 & 205.4 & 119.7 \\
\hline $\log (A G E)$ (years) & 28.1 & 19.5 & 14.0 & 10.1 \\
\hline TANGIBLE_ASSETS & 0.653 & 0.577 & 0.499 & 0.420 \\
\hline CAPEX & 0.073 & 0.077 & 0.077 & 0.066 \\
\hline PROFITABILITY & 0.160 & 0.143 & 0.109 & -0.012 \\
\hline PROFIT_VOLATILITY & 0.021 & 0.037 & 0.070 & 0.160 \\
\hline DIVIDEND_YIELD & 0.026 & 0.015 & 0.007 & 0.002 \\
\hline TOTAL_DEBT/MARKET_CAP & 0.646 & 0.740 & 0.754 & 0.727 \\
\hline TOTAL_DEBT/In(SIZE) (BV) & 0.098 & 0.119 & 0.146 & 0.190 \\
\hline CASH/MARKET_CAP & 0.548 & 0.621 & 0.608 & 0.538 \\
\hline NET_DEBT/MARKET_CAP & 0.452 & 0.453 & 0.433 & 0.402 \\
\hline DEBT_MATURITY & 0.391 & 0.393 & 0.355 & 0.291 \\
\hline COUPON_RATE & 0.038 & 0.038 & 0.036 & 0.033 \\
\hline
\end{tabular}


examine the differences in values between the first and fourth quartiles, we see that low-risk firms are about 7 times as large (in terms of total assets) and 3 times as old as high-risk firms. In addition, low-risk firms have 50\% more tangible assets than high-risk firms. Low-risk firms are highly profitable, whereas high-risk firms do not break even. Similarly, profit volatility of low-risk firms (0.021) is a very small fraction of that of high-risk firms (0.160). The dividend yield of low-risk firms is an order of magnitude greater than that of high-risk firms. In contrast, there is no clear relation between equity volatility and capital expenditures.

For financial characteristics, there are few obvious patterns across equity volatility quartiles. Specifically, total debt, net debt, and cash as a percentage of market capitalization exhibit no obvious trends across volatility quartiles. Debt maturity is slightly lower for high-risk firms, as is the coupon rate. Only total debt as a percentage of total assets shows a clear (in this case, upward) trend as risk increases. In sum, these results suggest that firm characteristics related to economic risks are more important than financial characteristics for explaining cross-sectional variation in equity volatility.

\section{B. LT Model Estimation and Results}

We now turn to estimating the LT (1996) model discussed above. Below we describe the exact specifications as well as the results of the estimation. We estimate both pooled regressions and Fama-MacBeth (1973)-style regressions. Pooled regressions do not assume time-series independence and are based on full information maximum likelihood. Therefore, they do not suffer from a direct errors-in-variables problem, an issue that is known to plague 2-pass procedures like Fama-MacBeth. However, unlike the Fama-MacBeth method, pooled regressions require the estimation of the error covariance matrix of the panel. This estimation is usually done by imposing an arbitrary structure on cross correlation and heteroskedasticity or by simply assuming a time-invariant covariance matrix. In contrast, the Fama-MacBeth procedure suffers from the errors-in-variables problem, but it allows estimation of the cross section without imposing any structure on the covariance matrix. (Fama and MacBeth (1973)). In general, the pooled regressions are likely to have more power if the relations between variables are stable, but potentially lead to poor inference if the relations between variables have unmodeled time trends. We subsequently examine trends in the Fama-MacBeth parameter estimates and find that some values appear to exhibit time trends (e.g., the effect of firm age). Thus, we caution the reader when interpreting the pooled estimate results. However, the methods usually provide similar results.

\section{LT Model Empirical Specification}

Estimating the LT (1996) model requires some additional assumptions. First, we set the asset value in each firm-year to 100 and scale other variables to this value when necessary. This standardization simplifies the numerical estimation. We use the 10-year constant maturity U.S. Treasury yield (compiled by the Federal Reserve Board) as a proxy for the risk-free rate, $r$. For the corporate income tax rate, $\tau$, we use the statutory rate for the highest income group as reported by 
the Tax Foundation. ${ }^{7}$ We assume a value of 0.4 for $\alpha$, the fraction of firm value lost in bankruptcy.

For other model inputs, we parameterize the values using firm-specific data. Most importantly, we specify

$$
\begin{aligned}
\sigma_{A}= & \exp \left\{\beta_{0}+\beta_{1} \ln (\mathrm{SIZE})+\beta_{2} \log (\mathrm{AGE})\right. \\
& +\beta_{3} \text { TANGIBLE_ASSETS }+\beta_{4} \text { CAPEX } \\
& +\beta_{5} \text { PROFITABILITY }+\beta_{6} \text { PROFIT_VOLATILITY } \\
& \left.+\beta_{7} \text { DIVIDEND_YIELD }\right\}
\end{aligned}
$$

where the $\beta_{i}$ parameters are estimated coefficients. ${ }^{8}$ We parameterize debt maturity to be between 1 and 10 years by defining

$$
T=1+9 \frac{\text { LONG_TERM_DEBT }+ \text { PREFERRED_STOCK }}{\text { TOTAL_DEBT }} .
$$

However our results are not meaningfully affected by this choice of maximum maturity. The face value of all outstanding debt $(P)$ is calculated as net book leverage adjusted by LEVERAGE_FACTOR to take into account endogenous financial policies not observed by the econometrician, so that

$$
P=\text { LEVERAGE_FACTOR } \times(\text { TOTAL_DEBT }-\mathrm{CASH}) .
$$

Consequently, the estimation adjusts LEVERAGE_FACTOR (and other parameters) to minimize the squared error of equity volatility as specified by the model. LEVERAGE_FACTOR greater than 1.0 would indicate that firms have more effective financial leverage than implied by the net debt ratio, perhaps because of off-balance-sheet financing such as operating leases, pension liabilities, or structured investment vehicles. Recent research suggests that reported debt levels may understate effective financial leverage (see Bartram (2015), Cornaggia, Franzen, and Simin (2011), and Shivdasani and Stefanescu (2010)), and thus we might reasonably expect a leverage factor greater than 1 . In contrast, LEVERAGE_FACTOR less than 1.0 would indicate that firms have less effective financial leverage than implied by the net debt ratio, perhaps because of various financial risk management policies such as cash management, insurance, dynamic capital structure, use of financial derivatives, or so-called alternative risk transfer techniques. ${ }^{9}$

We use the previously defined variables to define our proxy for the coupon rate $(C)$ so that

$$
C=\frac{\text { INTEREST_EXPENSE + PREFERRED_DIVIDENDS }}{\text { TOTAL_DEBT }} .
$$

\footnotetext{
${ }^{7}$ See http://www.taxfoundation.org/taxdata/show/2140.html

${ }^{8} \mathrm{~A}$ downside to our ad hoc specification for asset volatility is that unmodeled determinants of volatility might get absorbed into the constant. In the Internet Appendix we discuss estimating the model with a constant term in the leverage equation as an alternative.

${ }^{9}$ For example, an industrial firm with a financing arm may create a separate legal entity that reduces financial exposure for the firm even though the reporting of the entity's debt is consolidated on the firm's balance sheet.
} 
These observable variables allow for the calculation of all other variables in our optimization problem described in Section A of the Internet Appendix. ${ }^{10}$ Specifically, we note that this estimation procedure calibrates the model in a way that allows for the endogenous nature of the bankruptcy decision and financial policy in general. When estimating the LT (1996) model using the Fama-MacBeth (1973) method, the optimization converges in all years except 1999, 2008, and 2009; consequently, we exclude those years from the Fama-MacBeth part of the analysis.

\title{
2. LT Model Results
}

Table 3 reports the results of pooled and Fama-MacBeth (1973) estimations for the LT (1996) model. The pooled sample results show that all the economic risk factors we consider are statistically significant explanatory variables for equity volatility at better than the 0.001 confidence level. As suggested by the previous analysis, the volatility of equity decreases with firm size and age. Lower profitability and higher profit volatility increase equity volatility. More tangible assets and capital expenditures are associated with lower volatility. Dividend yield is negatively related to equity volatility. For Fama-MacBeth regressions, the results for firm characteristics are mostly similar in sign and significance. The exception is for tangible assets, which is not statistically significant. Marginal effects show that some factors have stronger effects on risk than others. In both specifications, firm size, profit volatility, and dividends exhibit the greatest effects.

\section{TABLE 3}

\section{Leland-Toft Model Estimation Results}

\begin{abstract}
Table 3 shows Leland-Toft (LT) (1996) model coefficient estimates, p-values, and marginal effects (MEs) from pooled and Fama-MacBeth (1973) regressions for the sample between 1964 and 2009. The table also provides predicted values and standard deviations for $\sigma_{A}$ (volatility of assets) and implied financial leverage (I) as defined in equations (5) and (2). Marginal effects are defined as the change in total risk resulting from a 1-standard-deviation increase (from the mean) in the independent variable, with other independent variables set to their mean values. In(SIZE) is the natural log of total assets (Compustat variable AT). $\log (\mathrm{AGE}$ ) is the difference between the measurement year and the minimum of $\mathrm{i}$ ) the year of listing data from Jovanovic and Rousseau (2001) and ii) the firm's initial appearance in the Center for Research in Security Prices (CRSP) monthly database. TANGIBLE_ASSETS is gross property, plant, and equipment divided by total assets. CAPEX is capital expenditures divided by total assets. PROFITABILITY is operating income before depreciation divided by sales. PROFIT_VOLATILITY is the 5-year central standard deviation of profitability. DIVIDEND_YIELD is common dividends divided by market capitalization (absolute value of closing price $\times$ shares outstanding from CRSP). LEVERAGE_FACTOR is defined in equation (7). All accounting data items are from Compustat.
\end{abstract}

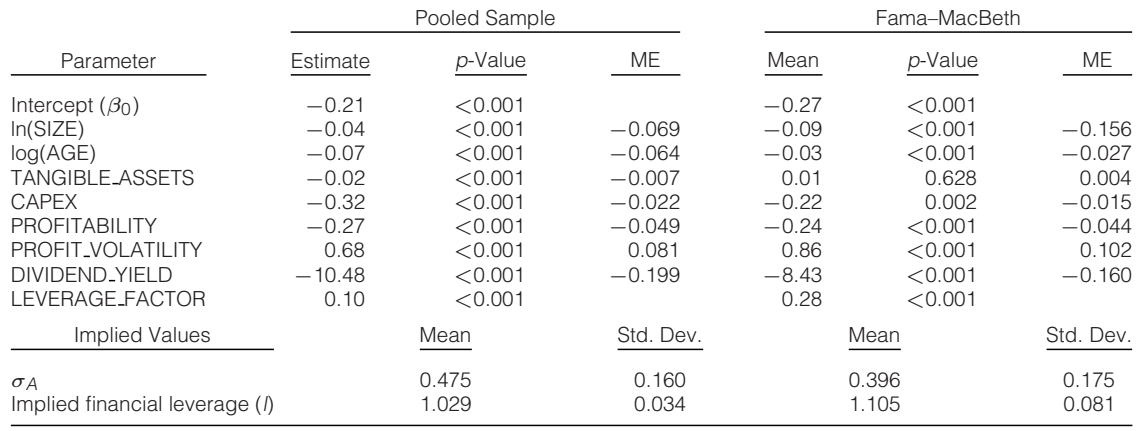

\footnotetext{
${ }^{10}$ In the optimization we use model estimates for equity value. Because actual values tend to be higher than model values, implied leverage would be even lower if we use actual equity values.
} 
These effects are economically large. For example, the marginal effect of 0.102 for profit volatility in the Fama-MacBeth specification indicates that as we move from the lower quartile break point to the upper quartile break point, the equity risk of a firm increases by about $50 \%$, ceteris paribus.

An important advantage of the LT (1996) specification is that it allows for the empirical appraisal of the importance of financial leverage through the estimation of LEVERAGE_FACTOR. For both estimations, the value of LEVERAGE_ FACTOR is low: 0.10 in the pooled specification and 0.28 in the Fama-MacBeth (1973) specification. The low values are surprising and suggest that the actual relation between financial leverage and equity volatility is substantially lower than would be inferred from a casual observation of the total debt ratio. We emphasize that the small value is not the result of low statistical power as the coefficient is significantly different from 0 (and 1.0) at better than the 0.001 level.

Table 3 also reports estimated values for asset volatility $\left(\sigma_{A}\right)$ and implied financial leverage $(l)$. The models do a good job of matching the cross-sectional variation of equity volatility as evidenced by the standard deviation of model estimates of $\sigma_{A}$. The values of 0.160 to 0.175 are in the range of the observed standard deviation of equity volatility (0.245). The values for market leverage (1.029 and 1.105) are close to 1.0. This result derives from the low estimated values for LEVERAGE_FACTOR. The implication of this result is that little of observed equity price risk can be attributed to financial leverage, and thus, the implied levels of financial risk are low. In addition, about $1 / 4$ of firms have implied leverage below 1.0, which suggests that these firms actually reduce their total risk with financial policy (e.g., with cash holdings in excess of debt that can serve as contingency reserves during periods of financial stress). We note that this finding is consistent with the distribution of net debt (not reported). Overall, our estimates of mean asset volatility ( 0.475 and 0.396$)$ differ little from the average equity volatility of 0.492 .

Graph A of Figure 1 compares actual leverage measures with LT (1996) model implied financial leverage. Actual leverage for net debt is always lower than actual leverage for total debt because of cash holdings. The changes in cash holdings are small compared to changes in total debt so that the series track each other closely. Actual leverage increased through the 1960s and early 1970s but then started to trend downward until 2000. However, our LT implied leverage measure suggests that since the late 1960s implied leverage is much lower than either measure of actual leverage. LT implied leverage shows neither the big longterm run-up nor the substantial decline of actual leverage.

Because our analysis of this type of structural model is novel, we also examine the potential for estimation bias. Our primary concern is that not explicitly accounting for measurement error of asset volatility or leverage separately could result in biased estimates of risk determinants or implied leverage (much like a traditional errors-in-variables problem). We investigate this possibility through a simulation analysis of unmodeled noise in asset volatility (i.e., in equation (5)) and in leverage (i.e., in equation (7)). The details of the analysis are provided in Section B of the Internet Appendix, and we briefly summarize them here.

The potential misspecification of asset volatility results in errors of indeterminate sign for the coefficient estimates but a consistent downward bias in implied 
FIGURE 1

Leverage Ratios and Volatility for the Leland-Toft Model

Graph A of Figure 1 plots average values for implied leverage from the Leland-Toft (LT) (1996) model estimation presented in Table 3, actual leverage calculated using total debt, and actual leverage using net debt. Total debt and net debt are as defined in Table 1. We also plot the LT measure adjusted for potential estimation bias as described in the Internet Appendix. Leverage is defined as 1.0 plus the relevant debt measure divided by the market value of equity. Graph B plots estimated levels of asset volatility from the LT model and equity volatility. Plotted values are annual estimates from 1964 to 2009. Recessions dated by the National Bureau of Economic Research are shaded in gray.

Graph A. Actual and Implied Leverage Ratios

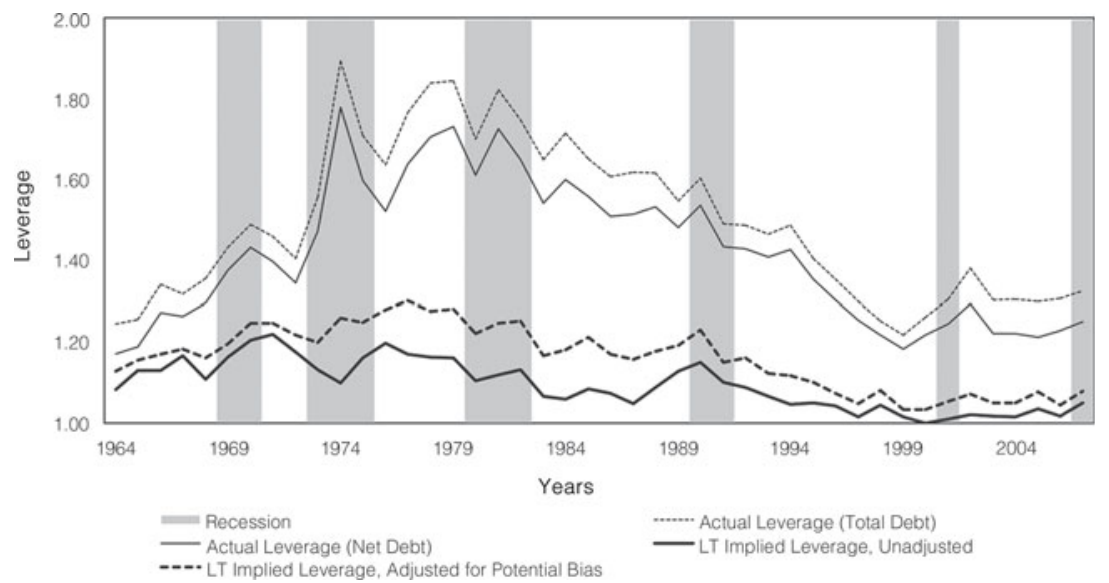

Graph B. Equity and Asset Volatilities

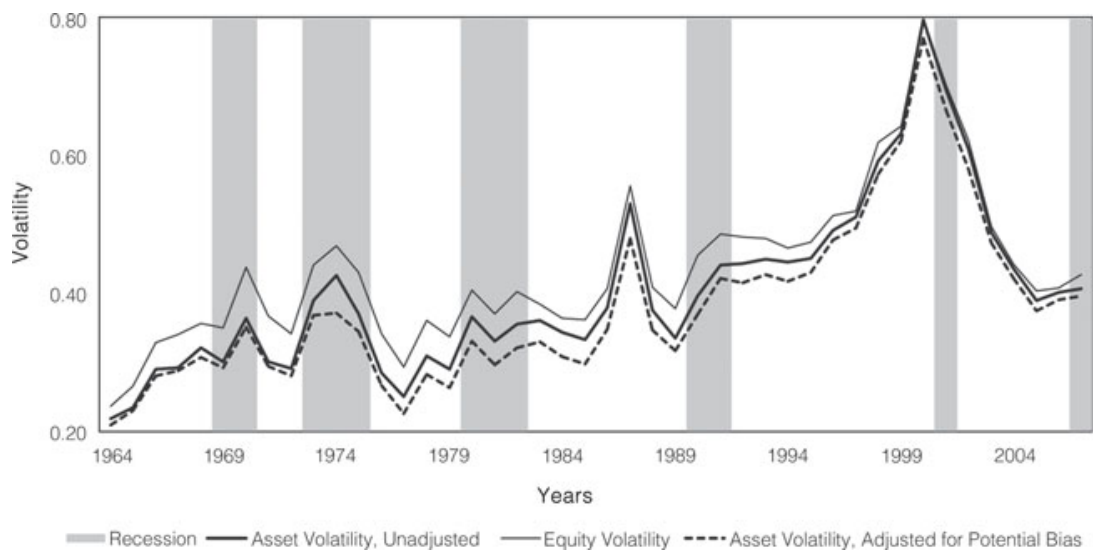

leverage and a consistent upward bias in implied asset volatility. These effects are small, even when we assume extremely high levels of measurement error for asset volatility. However, measurement error for financial leverage can lead to larger biases. Consequently, we also estimated LEVERAGE_FACTOR and asset volatilities that adjust for a reasonably high level of measurement error in net debt levels. Graph A of Figure 1 plots the LT (1996) implied leverage measures adjusted for potential bias.

The bias-adjusted LT (1996) implied leverage consistently plots above the unadjusted measure. The magnitude of the estimated bias increases during the 1970s and early 1980s, resulting in an implied leverage measure that more closely 
follows the observed leverage trend. However, the magnitude of implied leverage adjusted for bias is still low compared to actual leverage. Consequently, we are confident concluding that implied leverage is consistently much lower than observed leverage even in the case that our estimation suffers from estimation biases. It is also interesting to note that despite by-year estimation of the models, our measures of implied leverage are more stable than actual leverage measures.

Graph B of Figure 1 plots equity volatility and our estimates of asset volatility from the LT (1996) model. Because implied leverage is relatively stable compared to asset volatility, the two series track each other closely. The plots show the well-documented upward trend in firm risk from 1964 to 2000. In fact, asset volatility shows an even stronger trend than equity volatility because leverage tends to decline over this period. This result holds for both implied and actual leverage measures. It is consistent with the conclusions of previous research that finds that growth options, profit volatility, other characteristics associated with firm assets, and economic risk explain the trend in idiosyncratic risk (see, e.g., Irvine and Pontiff (2009), Cao, Simin, and Zhao (2008), and Brown and Kapadia (2007)). Overall, the average decline in leverage (both actual and implied) over the last 3 decades indicates that any upward trend in equity volatility was driven entirely by economic risk factors and that declines in financial risk actually mitigated the severity of the change.

Although our analysis with the LT (1996) model suggests that model misspecification and estimation bias are unlikely to drive our conclusions, it is impossible to know this with certainty. Consequently, we now turn to the time-series model evidence, which provides an entirely independent assessment of the importance of financial risk.

\section{Time-Series Model Results}

We follow the methodology described in Choi and Richardson (2009) and define asset returns as unlevered equity returns, using net debt as the measure of leverage. We also restrict our sample to $1991-2008$ initially. ${ }^{11}$ Table 4 provides summary statistics of quarterly data over this period for our full sample of firms. We also divide our sample into 5 groups based on the average level of net debt. Low $(<0.10)$ net debt firms are the largest group, making up $628(29.2 \%)$ of the 2,151 firms in our sample.

Table 5 presents results of model estimation for equity volatility for the augmented EGARCH model for the 5 leverage groups defined in Table 4. In addition to the firm characteristics of interest, we include the level of the Chicago Federal Reserve's National Activity Index to account for well-known time variation in volatility related to the business cycle. Inspection of the coefficients and marginal

\footnotetext{
${ }^{11}$ This represents the period of primary interest and matches the Choi and Richardson (2009) sample period, thus facilitating comparisons with their results. We thank the authors for providing a list of firms in their sample. Of the 853 firms in the Choi and Richardson sample, 641 are present in our sample. The primary difference in sample construction comes from Choi and Richardson selecting their sample based on the availability of publicly available information on debt issues. We do not limit our sample to firms with detailed debt data. As Choi and Richardson note, their sample firms tend to have significantly higher leverage and larger size than the CRSP universe (as well as our sample) because the bond database does not include small firms with small amounts of debt (p. 4).
} 


\section{TABLE 4}

Time-Series Sample Statistics

Table 4 reports summary statistics by leverage group for our full sample of firms. Break points for leverage groups are based on our net debt measure and correspond to those reported in Choi and Richardson (2009). We also restrict this sample period to the years 1991-2008 examined in Choi and Richardson. Data are quarterly and the reported values are means across pooled observations. In(SIZE) is the natural log of total assets (Compustat variable AT). log(AGE) is the difference between the measurement year and the minimum of i) the year of listing data from Jovanovic and Rousseau (2001) and ii) the firm's initial appearance in the Center for Research in Security Prices (CRSP) monthly database. TANGIBLE_ASSETS is gross property, plant, and equipment divided by total assets. CAPEX is capital expenditures divided by total assets. PROFITABILITY is operating income before depreciation divided by sales. PROFIT_VOLATILITY is the 5-year central standard deviation of profitability. DIVIDEND_YIELD is common dividends divided by market capitalization (closing price $\times$ shares outstanding from CRSP). TOTAL_DEBT/MARKET_CAP capitalization is long-term debt plus current liabilities plus preferred stock divided by market capitalization. CASH/MARKET_CAP is cash and short-term investments (STI) divided by market capitalization. NET_DEBT/MARKET_CAP is (total debt - cash and STI) divided by market capitalization. DEBT_MATURITY is long-term debt divided by total debt. Likewise, PROFIT_VOLATILITY is capped at 50\%. All accounting data items are from Compustat.

No. of firms

No. of firm-quarters

In(SIZE) (million)

$\log (A G E)$ (years)

TANGIBLE_ASSETS

CAPEX

PROFITABILITY

PROFIT_VOLATILITY

DIVIDEND_YIELD

TOTAL_DEBT/MARKET_CAP

CASH/MARKET_CAP

NET_DEBT/MARKET_CAP

DEBT_MATURITY

\begin{tabular}{|c|c|c|c|c|c|}
\hline & & $\begin{array}{l}\stackrel{\omega}{\rho} \\
\dot{0} \\
\text { V }\end{array}$ & $\begin{array}{l}\widetilde{U} \\
\stackrel{\bullet}{0} \\
V\end{array}$ & $\frac{8}{\dot{c}}$ & \\
\hline 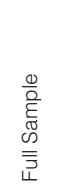 & 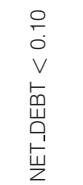 & 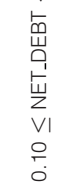 & 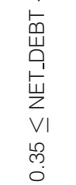 & 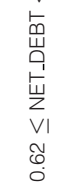 & 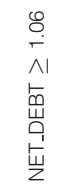 \\
\hline 2,151 & 628 & 503 & 383 & 310 & 327 \\
\hline 86,333 & 23,913 & 21,966 & 15,487 & 12,667 & 12,300 \\
\hline 2,216 & 987 & 2,555 & 3,662 & 2,725 & 1,829 \\
\hline 18.0 & 13.1 & 20.1 & 21.7 & 19.3 & 17.1 \\
\hline 0.596 & 0.414 & 0.639 & 0.696 & 0.712 & 0.637 \\
\hline 0.065 & 0.055 & 0.072 & 0.075 & 0.071 & 0.059 \\
\hline 0.051 & 0.000 & 0.073 & 0.087 & 0.069 & 0.054 \\
\hline 0.092 & 0.155 & 0.077 & 0.062 & 0.064 & 0.055 \\
\hline 0.007 & 0.004 & 0.008 & 0.010 & 0.000 & 0.000 \\
\hline 0.669 & 0.126 & 0.303 & 0.544 & 0.900 & 2.205 \\
\hline 0.105 & 0.167 & 0.070 & 0.061 & 0.067 & 0.128 \\
\hline 0.554 & -0.042 & 0.223 & 0.468 & 0.817 & 2.058 \\
\hline 0.646 & 0.885 & 0.651 & 0.529 & 0.496 & 0.450 \\
\hline
\end{tabular}

effects indicates that many of the firm characteristics are both statistically and economically important in the same ways as in the LT (1996) model estimation. For example, firm size and dividend yield have strong negative relations to equity volatility, whereas profit volatility has a strong positive relation. Total debt also has a large positive effect on equity volatility, suggesting that financial leverage is an important factor for determining total risk. ${ }^{12}$

Implicit in our analysis is an assumption that firms will adjust financial policies based on the characteristics we have chosen for modeling asset volatility. As a consequence, we should expect that firms with different leverage profiles would have different risk sensitivities to the factors we examine. Overall, the EGARCH parameters in Table 5 are very stable across the groups. In contrast, firm characteristics have varying effects, with some increasing and others decreasing in importance with higher debt levels. We still observe that for each of the groups,

\footnotetext{
${ }^{12}$ In Table A.9 of the Internet Appendix we report results for estimation using the full sample and both equity and asset volatilities as the dependent variables. Model estimation for asset volatility reveals similar results for the asset characteristics. The coefficient on total debt is negative in the asset volatility model, suggesting that firms with high asset volatility have lower debt. This result combined with the positive coefficients on cash holdings and debt maturity provides further support for the theory that firms with riskier operations will undertake more conservative financial policies in an attempt to manage the level of total risk.
} 


\section{TABLE 5}

\section{Equity Volatility Time-Series Model Estimates by Leverage Group}

Table 5 reports estimated coefficients, $p$-values, and marginal effects for the augmented exponential generalized autoregressive conditional heteroskedasticity (EGARCH) model by leverage group. The model being estimated is defined in the main text in equations (3) and (4). We also restrict this sample period to 1991-2008 examined in Choi and Richardson (2009). Marginal effects (MEs) are changes in volatility for a 1-standard-deviation change in the firm characteristic. Estimation is conducted using the pooled sample of quarterly returns. Firm characteristics are defined in Table 4. CFNAl is the Chicago Federal Reserve's National Activity Index.

\begin{tabular}{|c|c|c|c|c|c|c|c|c|c|c|c|c|c|c|c|}
\hline & \multicolumn{3}{|c|}{ NET_DEBT $<0.10$} & \multicolumn{3}{|c|}{$0.10 \leq$ NET_DEBT $<0.35$} & \multicolumn{3}{|c|}{$0.35 \leq$ NET_DEBT $<0.62$} & \multicolumn{3}{|c|}{$0.62 \leq$ NET_DEBT $<1.06$} & \multicolumn{3}{|c|}{ NET_DEBT $\geq 1.06$} \\
\hline & Est. & $\underline{p \text {-Value }}$ & $\mathrm{ME}$ & Est. & $\underline{p \text {-Value }}$ & ME & Est. & $\underline{p \text {-Value }}$ & $\mathrm{ME}$ & Est. & $\underline{p \text {-Value }}$ & $\mathrm{ME}$ & Est. & $\underline{p \text {-Value }}$ & ME \\
\hline $\begin{array}{l}\text { EGARCH Parameters } \\
c \\
\alpha \\
\beta \\
\gamma\end{array}$ & $\begin{array}{r}-0.077 \\
0.363 \\
0.858 \\
-0.122\end{array}$ & $\begin{array}{l}<0.001 \\
<0.001 \\
<0.001 \\
<0.001\end{array}$ & & $\begin{array}{r}-0.237 \\
0.357 \\
0.831 \\
-0.110\end{array}$ & $\begin{array}{r}0.092 \\
<0.001 \\
<0.001 \\
<0.001\end{array}$ & & $\begin{array}{r}-0.389 \\
0.349 \\
0.823 \\
-0.128\end{array}$ & $\begin{array}{l}<0.001 \\
<0.001 \\
<0.001 \\
<0.001\end{array}$ & & $\begin{array}{r}-0.464 \\
0.304 \\
0.804 \\
-0.106\end{array}$ & $\begin{array}{r}0.056 \\
<0.001 \\
<0.001 \\
<0.001\end{array}$ & & $\begin{array}{r}-0.168 \\
0.273 \\
0.872 \\
-0.129\end{array}$ & $\begin{array}{l}<0.001 \\
<0.001 \\
<0.001 \\
<0.001\end{array}$ & \\
\hline $\begin{array}{l}\text { Firm Characteristics } \\
\text { In(SIZE) } \\
\text { log(AGE) } \\
\text { TANGIBLE_ASSETS } \\
\text { CAPEX } \\
\text { PROFITABILITY } \\
\text { PROFIT_VOLATILITY } \\
\text { DIVIDEND_YIELD } \\
\text { TOTAL_DEBT/MARKET_CAP } \\
\text { CASH/MARKET_CAP } \\
\text { DEBT_MATURITY }\end{array}$ & $\begin{array}{r}-0.040 \\
-0.023 \\
0.085 \\
-0.412 \\
0.038 \\
0.591 \\
-4.315 \\
0.144 \\
-0.130 \\
-0.018\end{array}$ & $\begin{array}{r}<0.001 \\
<0.001 \\
<0.001 \\
<0.001 \\
0.068 \\
<0.001 \\
<0.001 \\
<0.001 \\
<0.001 \\
0.195\end{array}$ & $\begin{array}{r}-0.029 \\
-0.007 \\
0.012 \\
-0.008 \\
0.002 \\
0.030 \\
-0.019 \\
0.049 \\
-0.006 \\
-0.002\end{array}$ & $\begin{array}{r}-0.044 \\
-0.003 \\
-0.005 \\
0.027 \\
0.026 \\
0.438 \\
-4.238 \\
0.142 \\
0.016 \\
0.022\end{array}$ & $\begin{array}{r}<0.001 \\
0.442 \\
0.625 \\
0.655 \\
0.381 \\
<0.001 \\
<0.001 \\
<0.001 \\
0.610 \\
0.130\end{array}$ & $\begin{array}{r}-0.023 \\
-0.001 \\
-0.000 \\
0.000 \\
0.001 \\
0.016 \\
-0.013 \\
0.035 \\
0.001 \\
0.002\end{array}$ & $\begin{array}{r}-0.034 \\
0.006 \\
-0.022 \\
-0.037 \\
-0.012 \\
0.478 \\
-3.334 \\
0.099 \\
0.135 \\
0.089\end{array}$ & $\begin{array}{r}<0.001 \\
0.190 \\
0.054 \\
0.602 \\
0.767 \\
<0.001 \\
<0.001 \\
<0.001 \\
<0.001 \\
<0.001\end{array}$ & $\begin{array}{r}-0.016 \\
0.001 \\
-0.002 \\
-0.001 \\
-0.000 \\
0.016 \\
-0.010 \\
0.022 \\
0.004 \\
0.006\end{array}$ & $\begin{array}{r}-0.035 \\
-0.010 \\
0.021 \\
-0.110 \\
0.034 \\
0.398 \\
-3.615 \\
0.083 \\
0.019 \\
0.174\end{array}$ & $\begin{array}{r}<0.001 \\
0.032 \\
0.086 \\
0.176 \\
0.459 \\
<0.001 \\
<0.001 \\
<0.001 \\
0.638 \\
<0.001\end{array}$ & $\begin{array}{r}-0.016 \\
-0.002 \\
0.002 \\
-0.001 \\
0.001 \\
0.013 \\
-0.010 \\
0.018 \\
0.001 \\
0.012\end{array}$ & $\begin{array}{r}-0.029 \\
0.002 \\
0.012 \\
-0.155 \\
-0.224 \\
0.255 \\
-2.045 \\
0.032 \\
-0.023 \\
-0.015\end{array}$ & $\begin{array}{r}<0.001 \\
0.634 \\
0.219 \\
0.017 \\
<0.001 \\
<0.001 \\
<0.001 \\
<0.001 \\
0.193 \\
0.344\end{array}$ & $\begin{array}{r}-0.017 \\
0.000 \\
0.001 \\
-0.003 \\
-0.011 \\
0.010 \\
-0.007 \\
0.009 \\
-0.001 \\
-0.001\end{array}$ \\
\hline $\begin{array}{l}\text { Macro Characteristics } \\
\text { CFNAI }\end{array}$ & 0.014 & 0.038 & 0.004 & -0.062 & $<0.001$ & -0.011 & -0.075 & $<0.001$ & -0.013 & -0.098 & $<0.001$ & -0.016 & -0.076 & $<0.001$ & -0.016 \\
\hline No. of firms & 628 & & & 503 & & & 383 & & & 310 & & & 327 & & \\
\hline
\end{tabular}


several of the firm characteristics are important. For the asset characteristics, firm size and profit volatility consistently have the greatest effects on equity volatility. Dividend yield also has a large and consistently negative relation to risk.

The most interesting result in these tests comes from observing the effects related to total debt. The effect of debt on total risk decreases monotonically as debt levels increase, and the decline is substantial in both absolute and relative terms. Specifically, total debt is by far the most important determinant of risk for the lowest leverage group, with a marginal effect of 0.049 , or $4.9 \%$ annualized standard deviation. For the highest leverage group, the marginal effect of total debt falls to 0.009 and is only the fourth most important determinant of total risk. The fact that the relative importance and marginal effects for total debt get smaller as leverage increases is consistent with firms with high debt levels undertaking more financial risk management. If the expected costs of financial distress increase with leverage (e.g., the probability of distress increases), this would be the expected strategy as long as there exist costs associated with running a risk management program. For example, previous research suggests that there are both significant fixed and variable costs of hedging with derivatives (see Brown (2001)). This does not mean that firms with low levels of leverage do not manage financial risk, just that these firms appear not to do so to the same degree as firms with higher leverage. Likewise, this finding is consistent with firms that have a very high sensitivity to debt choosing a very low exposure to financial risk. For the other financial risk factors (cash and debt maturity), the coefficients are only sometimes statistically significant, and the marginal effects are typically small.

Overall, the results of the augmented EGARCH analysis suggest that factors hypothesized to be associated with both asset characteristics (e.g., size and profit volatility) and financial policy (e.g., total debt) are important for determining equity volatility. In contrast to our analysis using the LT (1996) model, the consistently positive and statistically significant relation between total debt and risk suggests that financial risk is an economically important determinant of equity volatility. However, we find the biggest sensitivities for firms with the least amount of debt and during the recent period of relatively low debt levels. Consequently, it is not possible to determine from the previous analysis the relative importance of these effects. To gain insight into the overall importance of financial risk, we conduct a volatility decomposition (as in Choi and Richardson (2009)) to identify how much of total risk can be attributed to asset volatility and how much to financial leverage. The results are presented in Table 6.

The conclusions of this analysis are similar to those obtained for the LT (1996) model insofar as a large majority of equity volatility can be attributed to asset volatility. For the median (average) firm, asset volatility accounts for $84.7 \%$ $(67.6 \%)$ of equity volatility. These summary values conceal substantial variation across leverage groups. Despite the much higher sensitivities to total debt for low-leverage firms (documented in Table 5), the vast majority of equity volatility is accounted for by asset volatility for the lowest leverage group. As leverage increases, the importance of financial risk increases monotonically. For the two highest leverage groups, financial risk accounts for the majority of equity volatility. In fact, for the highest leverage firms, the importance of financial risk is pronounced. However, this group consists of just $15.2 \%$ of firms and $6.3 \%$ of total assets in our sample. 
TABLE 6

Volatility Decomposition from Time-Series Model Estimates

Table 6 reports estimates of equity volatility contributions from asset volatility and financial risk (Asset/Equity) as described in Choi and Richardson (2009). We restrict the sample period to 1991-2008. Mean and median values are reported for all firms and by leverage group. The model being estimated is defined in the main text in equations (3) and (4). Asset returns used to estimate the asset volatility model are derived from dividing equity returns by $(1+$ debt/equity). Estimation is conducted using the pooled sample of quarterly returns.

\begin{tabular}{|c|c|c|c|c|c|}
\hline & \multirow[b]{2}{*}{ No. of Firms } & \multicolumn{2}{|c|}{ Mean } & \multicolumn{2}{|c|}{ Median } \\
\hline & & Asset/Equity & Asset Volatility & Asset/Equity & Asset Volatility \\
\hline NET_DEBT $<0.10$ & 628 & $7.3 \%$ & $92.7 \%$ & $1.6 \%$ & $98.4 \%$ \\
\hline $0.10 \leq$ NET_DEBT $<0.35$ & 503 & $23.3 \%$ & $76.7 \%$ & $15.8 \%$ & $84.2 \%$ \\
\hline $0.35 \leq$ NET_DEBT $<0.62$ & 383 & $40.5 \%$ & $59.5 \%$ & $34.7 \%$ & $65.3 \%$ \\
\hline $0.62 \leq$ NET_DEBT $<1.06$ & 310 & $59.1 \%$ & $40.9 \%$ & $59.2 \%$ & $40.8 \%$ \\
\hline NET_DEBT $\geq 1.06$ & 327 & $92.6 \%$ & $7.4 \%$ & $100.0 \%$ & $0.0 \%$ \\
\hline All firms & 2,151 & $32.4 \%$ & $67.6 \%$ & $15.3 \%$ & $84.7 \%$ \\
\hline
\end{tabular}

Overall, the analysis using time-series models is complementary to the analysis using the LT (1996) model. In both cases, we were able to identify important firm characteristics that are significantly related to equity volatility. The most important of these appear to be firm size, profit volatility, and dividend policy. Other factors seem to be of secondary importance for the typical firm, though the level of debt appears to be the driving force of risk for a relatively small number of highly leverage firms. In general, it is worth noting that the methodology seems able to identify firms where financial risk is important, but these firms are the exception rather than the rule.

\section{Additional Tests}

In this section we discuss results from alternative specifications and robustness tests.

\section{A. Reality Check}

Given the surprising nature of our results, it seems worthwhile to step back and see if our results are consistent with other broad trends in corporate finance. As already shown in Figure 1, actual debt levels (as well as our implied debt levels) have declined steadily since about 1980 . One drawback to this analysis is that it does not consider the cash flows associated with financial leverage and in particular the interest expense associated with debt. If firms are becoming riskier, it may be that interest expense has increased as firms must pay larger risk premiums to lenders. On the other hand, interest rates in most countries, including the United States, have trended down since the early 1980s. Even if interest expense does not increase for a typical firm, lower and more volatile income (e.g., associated with the many new and younger public firms) could mean that effective debt burdens have increased. If firms are in fact reducing financial leverage to negligible levels, this should be reflected in cash flows associated with whatever policies are being used to reduce risks. In short, if financial risks are declining toward 0 , the cash-flow burden of leverage should be following a similar trend. 
To investigate these issues, we calculate total interest expense as a percentage of total operating income each year for our sample of firms. To smooth out cyclical variation in operating income, we calculate a 5-year centered moving average. The dotted line in Figure 2 plots the result. The broad trends in this measure mimic the trends in actual leverage plotted in Figure 1. The relative burden of debt increases by a factor of 3 from 1964 to 1984 and then declines by about a half from 1990 to the end of the sample. Nonetheless, the ratio in 2009 is still at roughly the same level as in 1970, suggesting that leverage may continue to be a significant source of financial risk. A significant shortcoming of this ratio is that it does not account for other policies that could mitigate (or exacerbate) the risks of debt such as liquidity management, dividend policy, or risk management with derivatives. To adjust for the net effect of other financial policies on the cash flows of firms, we adjust interest expense by the change in cash holdings and again calculate the ratio to operating income. The solid line in Figure 2 plots this series. Surprisingly, large increases in cash holdings after 1990 offset interest expenses on debt so that by 2003 this ratio is 0 . Since 2003 the ratio has increased but remains below the lowest level measured before 2000 .

\section{FIGURE 2}

\section{Aggregate Interest Expense}

Figure 2 plots centered 5-year moving averages of aggregate interest expense and aggregate interest expense less the aggregate change in cash and short-term investments scaled by operating income over the 1964-2009 sample period. The dotted line plots the sum of interest expense (Compustat field XINT) across firms in our sample in a given year scaled by the sum of operating income (OIBDP). The solid line plots the sum of interest expense less the year-on-year change in cash and short-term investments (CHE) scaled by the sum of operating income. Recessions dated by the National Bureau of Economic Research are shaded in gray.

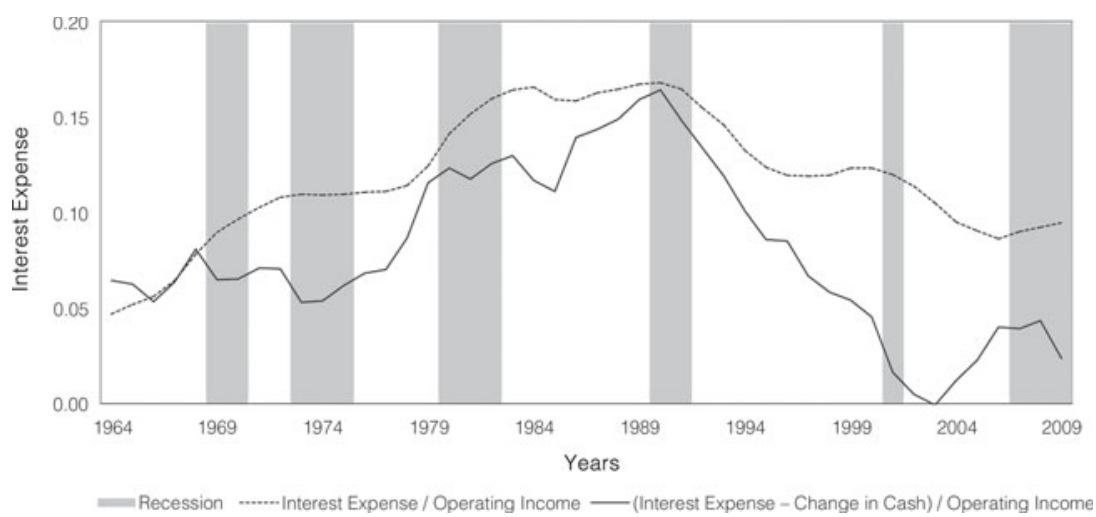

Although this analysis cannot document the precise sources of these increased cash holdings, they are no doubt the result of deliberate policies that result in a reduction of financial risks. Most important, this analysis shows that our estimates of increasingly low implied financial risk levels are consistent with the actual cash-flow positions of nonfinancial firms.

\section{B. Other Tests}

Our analysis is that the market is able to look through accounting data and determine the actual level of financial risk that a firm is taking. One way to gauge 
the accuracy of this assumption is to compare explicit measures of financial distress based on accounting data versus measures that also use market data. ${ }^{13}$ More specifically, the difference between accounting-based and market-based distress measures should be related to the difference between actual leverage and our implied leverage estimates. We use the Altman (1968) Z-score as a more marketbased measure of distress because it includes the market value of the firm as one of its components. We use the Ohlson (1980) $O$-score as a purely accounting-based measure of distress as it includes only accounting-based components. Using a variety of methods, we compare the differences in ranks for these two measures with the differences in actual and implied leverage, and find a consistently positive and statistically significant relation (detailed results are presented in the Internet Appendix, Table A.10). This finding is consistent with the market being able to evaluate the true financial risk levels of firms beyond what is implied by accounting data alone.

Section B of the Internet Appendix provides a detailed discussion of results from robustness tests that we briefly summarize here. First, we explore the determinants of firm risk over time. We find that the LEVERAGE_FACTOR estimate from the LT (1996) model has declined from values near 0.6 in the early 1970s to around 0.1 in the late 1990s. This finding suggests that financial risk has had a dampening effect on the time trend in equity volatility when combined with declines in both total and net debt over the same period. The decline in financial risk over this period is also consistent with the growing trend in financial risk management.

Next, we present results from a less restrictive reduced-form model of firm risk that are similar to our main results. Financial risk, including leverage related to total debt, does not appear to have a substantial effect on equity volatility for the typical firm. Consequently, the form of the model we use does not seem to matter much for our conclusions.

Finally, our LT (1996) model results hold for alternative specifications. We also verify that a potential misspecification in asset volatility does not seem to affect estimates for the lowest leverage group of firms in that market leverage is estimated to be insignificantly different from 1.0 (unleveled firms) in both the pooled and Fama-MacBeth (1973) estimations. Moreover, reestimating the LT model for each leverage group results in implied leverage estimates that increase with actual leverage but at a slower rate, consistent with higher leverage firms managing financial risk more. For example, estimates that include information on the use of financial derivatives suggest that this type of risk management explains about $1 / 4$ of the difference between actual and implied leverage.

\section{Conclusions}

Financial policy can be viewed as transforming asset volatility into equity volatility through net financial leverage. In this article, we study this relation using data for the United States between 1964 and 2009 in a unifying framework

\footnotetext{
${ }^{13}$ We thank the referee for making this suggestion.
} 
suggested by LT (1996) and a time-series (EGARCH) model that includes firm characteristics. To the best of our knowledge, no empirical study has attempted to analyze the determinants of firm risk using structural and time-series models with a large number of choice variables.

The results of our analysis are surprising. Despite the sizable actual leverage ratio of about 1.5 , implied leverage as estimated by our implementation of the LT (1996) model is within the range of only 1.03 to 1.11 . When we conduct an entirely independent variance decomposition based on the estimation of our augmented EGARCH model, we find that asset volatility accounts for $84.7 \%$ of total volatility for the median firm. Thus, using these two separate methods, we measure a relatively small wedge between asset and equity volatilities for the typical firm. As would be expected, implied financial risk is higher for the relatively small number of firms with high leverage. However, even many of these firms appear to have significantly lower implied leverage than book leverage. In addition, implied leverage seems to be declining over the last 3 decades in contrast to the upward trend in asset volatility.

Results for firm characteristics are also interesting. We find that the variation in equity volatility is driven primarily by economic risk factors. Specifically, we find that larger firms with more mature lines of business, higher profitability, and lower profit volatility have significantly lower firm risk. Financial risk factors tend to have a smaller effect on firm risk in general. This pattern is consistent with the hypothesis that carefully implemented financial policy has helped U.S. firms effectively manage financial risks.

In short, our results suggest that, as a practical matter, residual financial risk is now relatively unimportant for the typical U.S. firm. This finding raises questions about the level of expected financial distress costs, as the probability of financial distress is likely to be lower than assumed for most companies. For example, our results suggest that estimates of the level of systematic risk in bond pricing may be biased if they do not take into account the trend in implied financial leverage (e.g., Dichev (1998)). Our results also bring into question the appropriateness of financial models used to estimate default probabilities, as financial policies that may be difficult to observe appear to significantly reduce risk. In essence, this relation makes the credit spread puzzle even more puzzling. Finally, our results imply that the fundamental risks borne by shareholders are primarily related to underlying economic risks, which should lead to a relatively efficient allocation of capital in the corporate nonfinancial sector.

Some readers may be tempted to interpret our results as indicating that financial risk does not matter. This view is not the correct interpretation. Instead, our results suggest that firms choose (or manage) financial risk so that the resulting exposure to shareholders is usually low compared to economic risks. Of course, financial risk is important to firms that choose to take on such risks through high debt levels, high interest rate exposure, poor liquidity management, a lack of risk management, and so on. However, our study suggests that the typical nonfinancial firm chooses not to take significant financial risks. This finding contrasts with fundamental economic and business risks that are more difficult (or undesirable) to hedge because they represent the mechanism by which the firm earns economic profits. 
In summary, despite some fractured evidence in the literature, we have yet to understand the fundamental drivers of firm risk. As such, our results have important implications for many areas of finance. For example, our analysis informs the corporate finance literature in its attempt to identify relevant risk factors for firm valuation, and investment and financing policies. Delineating between economic risk and financial risk and identifying the drivers of these risks provide a basis for effective risk management. Our results are also important for asset pricing models that attempt to identify and quantify prevalent properties of firm and marketwide risk.

\section{References}

Acharya, V. V.; H. Almeida; and M. Campello. "Is Cash Negative Debt? A Hedging Perspective on Corporate Financial Policies.” Journal of Financial Intermediation, 16 (2007), 515-554.

Altman, E. I. "Financial Ratios, Discriminant Analysis and the Prediction of Corporate Bankruptcy." Journal of Finance, 23 (1968), 589-609.

Bartram, S. M. "Corporate Post-Retirement Benefit Plans and Leverage." Review of Finance, forthcoming (2015).

Bartram, S. M.; G. W. Brown; and J. Conrad. "The Effects of Derivatives on Firm Risk and Value." Journal of Financial and Quantitative Analysis, 46 (2011), 967-999.

Bartram, S. M.; G. W. Brown; and F. R. Fehle. "International Evidence on Financial Derivatives Usage.” Financial Management, 38 (2009), 185-206.

Bates, T. W.; K. M. Kahle; and R. M. Stulz. "Why Do U.S. Firms Hold So Much More Cash Than They Used To?” Journal of Finance, 64 (2009), 1985-2021.

Black, F., and J. C. Cox. "Valuing Corporate Securities: Some Effects of Bond Indenture Provisions." Journal of Finance, 31 (1976), 351-367.

Black, F., and M. Scholes. "The Pricing of Options and Corporate Liabilities." Journal of Political Economy, 81 (1973), 637-654.

Brown, G. W. "Managing Foreign Exchange Risk with Derivatives." Journal of Financial Economics, 60 (2001), 401-448.

Brown, G. W., and N. Kapadia. "Firm-Specific Risk and Equity Market Development." Journal of Financial Economics, 84 (2007), 358-388.

Cao, C.; T. Simin; and J. Zhao. "Can Growth Options Explain the Trend in Idiosyncratic Risk?" Review of Financial Studies, 21 (2008), 2599-2634.

Choi, J., and M. Richardson. "The Volatility of the Firm's Assets." Working Paper, New York University (2009).

Christie, A. A. "The Stochastic Behavior of Common Stock Variances: Value, Leverage and Interest Rate Effects.” Journal of Financial Economics, 10 (1982), 407-432.

Cornaggia, K.; L. Franzen; and T. Simin. "Manipulating the Balance Sheet? Implications of Off-Balance-Sheet Lease Financing." Working Paper, Pennsylvania State University (2011).

Dichev, I. D. "Is the Risk of Bankruptcy a Systematic Risk?" Journal of Finance, 53 (1998), $1131-1147$.

Eom, Y. H.; J. Helwege; and J. Huang. "Structural Models of Corporate Bond Pricing: An Empirical Analysis." Review of Financial Studies, 17 (2004), 499-544.

Fama, E., and J. MacBeth. "Risk, Return and Equilibrium: Empirical Tests." Journal of Political Economy, 81 (1973), 607-636.

Gilson, S. C. "Transactions Costs and Capital Structure Choice: Evidence from Financially Distressed Firms." Journal of Finance, 52 (1997), 161-196.

Irvine, P. J., and J. Pontiff. "Idiosyncratic Return Volatility, Cash Flows, and Product Market Competition." Review of Financial Studies, 22 (2009), 1149-1177.

Jovanovic, B., and P. L. Rousseau. "Why Wait? A Century of Life before IPO." American Economic Review, 91 (2001), 336-341.

Leland, H. E., and K. B. Toft. "Optimal Capital Structure, Endogenous Bankruptcy, and the Term Structure of Credit Spreads.” Journal of Finance, 51 (1996), 987-1019.

Merton, R. C. "On the Pricing of Corporate Debt: The Risk Structure of Interest Rates." Journal of Finance, 29 (1974), 449-470.

Nelson, D. B. "Conditional Heteroskedasticity in Asset Returns: A New Approach.” Econometrica, 59 (1991), 347-370. 


\section{Journal of Financial and Quantitative Analysis}

Ohlson, J. A. "Financial Ratios and the Probabilistic Prediction of Bankruptcy." Journal of Accounting Research, 18 (1980), 109-131.

Opler, T.; L. Pinkowitz; R. H. Stulz; and R. Williamson. "The Determinants and Implications of Corporate Cash Holdings.” Journal of Financial Economics, 52 (1999), 3-46.

Pástor, L., and P. Veronesi. "Stock Valuation and Learning about Profitability." Journal of Finance, 58 (2003), 1749-1790.

Rosenberg, B., and W. McKibben. "The Prediction of Systematic and Specific Risk in Common Stocks." Journal of Financial and Quantitative Analysis, 8 (1973), 317-333.

Schwert, G. W. "Why Does Stock Market Volatility Change over Time?" Journal of Finance, 44 (1989), 1115-1153.

Shivdasani, A., and I. Stefanescu. "How Do Pensions Affect Corporate Capital Structure Decisions?" Review of Financial Studies, 23 (2010), 1287-1323. 